\title{
FACTORS ASSOCIATED WITH WORK PERFORMANCE OF MIDWIVES AT LANGSA HOSPITAL, ACEH
}

\author{
Herna Linda' ${ }^{\text {) }}$ Zulfendri²), Juanita ${ }^{2)}$ \\ 1)Masters Program in Hospital Administration, Faculty of Public Health, \\ Universitas Sumatera Utara \\ ${ }^{2)}$ Department of Health Policy and Administration, Universitas Sumatera Utara
}

\begin{abstract}
Background: Recently, in some countries a framework for quality maternal and newborn care was developed, which encourages a system-level shift to provide skilled care for all. This care includes preventive and supportive care that works to strengthen women's capabilities and focuses on promotion of normal reproductive processes while ensuring access to emergency treatment when needed. Midwives with high work performance have an important role in this new system. This study aimed to determine factors associated with work performance among midwives at Langsa Hospital, Aceh, with special attention to the effect of motivation.

Subjects and Method: This was a cross sectional study conducted at General Hospital in Langsa, Aceh. A sample of 47 midwives was selected for this study. The dependent variable was work performance. The independent variables were employment status, skill, motivation, supervision, and training. The data were collected by questionnaire and analyzed by a multiple logistic regression.

Results: High motivation improved work performance of midwives $(\mathrm{OR}=2.35 ; \mathrm{p}=$ o.037), after controlling for the effects of employment status, skill, training, and supervision.

Conclusion: High motivation improves work performance of midwives.
\end{abstract}

Keywords: work performance, motivation, employment status, supervision, training, skill, midwife.

\section{Correspondence:}

Herna Linda. Masters Program in Hospital Administration, Faculty of Public Health, Universitas Sumatera Utara, North Sumatera.

Email: hernalinda875@yahoo.com. Mobile: 085275043919.

The 4th International Conference on Public Health Best Western Premier Hotel, Solo, Indonesia, August 29-30, 2018 | 239 https://doi.org/10.26911/theicph.2018.04.07 